\title{
PRODUCTIVITY OF ROTARY PARLOURS
}

\author{
Maris Mangalis, Juris Priekulis \\ Latvia University of Life Sciences and Technologies, Latvia \\ maris.mangalis@inbox.lv, juris.priekulis@llu.lv
}

\begin{abstract}
The aim of the research is to evaluate the efficiency of rotary type milking equipment depending on the number of animals on the rotating platform and its rotation speed. The number of milking places is a constant number for every particular milking equipment, but the speed of platform rotation can be changed adapting it to the lengths of milking cows, so that they could be milked within one revolution of the platform or within the rotation cycle. Seven rotary type parlours with 20 to 80 milking sites were included in the research. The input data necessary for the research were obtained in the process of milking in the result of timekeeping. In the research it has been found that the time of the cycle preset for rotation of the milking equipment is approximately equal with the theoretically calculated time of the cycle, and in most cases that is within the range from 7 to 19 minutes. In turn, in the conditions of exploitation the time of the operation cycle usually is in the range from 12 to 15 minutes. Whereas the productivity of work of the rotary parlour, that is calculated per one milking place, is approximately four cows per hour, and it practically does not depend on the pre-set rotation cycle time. Besides, the productivity of the rotary parlour is directly proportional to the number of milking sites in it.
\end{abstract}

Keywords: cows, milking, rotary, parlour, productivity.

\section{Introduction}

In recent years in Latvia milk farming has experienced serious problems that were created by the changes in the world milk market business. Also suspension of milk quotas and following it the fast drop of milk purchasing prices were a serious challenge for the Latvian milk farmers. Nevertheless, despite of these difficulties milk farming in the country has not diminished and it still continues to develop - new cow barns are built and they are equipped with modern animal farming machinery.

In the large milk cow barns, where the herd exceeds 300 animals, often conveyor type milking stands or rotary type equipment are used [1]. The number of milking places in such equipment can vary within the range from 16 to 80 , or even 100 places. The advantage of such equipment is comparatively high operational productivity. Besides, there is a possibility to ensure a high degree of automation of working operations. In Latvia, there are already about 20 kinds of such equipment and they differ in the number of milking places, location of cows on the rotating platform during milking, the number of milkers and organisation of work [2].

Rotary type milking equipment exploitation parameters have already been investigated in Latvia [2-4] as well as in other countries [5-7]. But till now the researchers have not paid special attention to the pre-set time of rotating of the rotary parlour and its influence on the productivity of the milking equipment. The productivity of the parlour is also influenced by cow behavior in the waiting area [8; 9]. Therefore, in the present article this issue is discussed based on the chronometer data obtained in several farms.

\section{Materials and methods}

If for milking of cows rotary type or conveyor type equipment is used, the cows have to be milked within one revolution of the platform. Therefore, the following formula should be valid

$$
T_{c . k} \geq T_{c}=t_{\text {ieie }}+t_{o}+t_{a p}+k t_{a p}+t_{i z i e}
$$

where $T_{c . k}$ - length of one revolution of the platform or rotation cycle, $\mathrm{s}$;

$T_{c}$ - average length of milking one cow, s;

$t_{\text {ieie }}$ - time spent for a cow entering the milking place on the rotary platform, s;

$t_{o}$ - consumption of milker's work calculating per one cow, s;

$t_{a}$ - length of milking, s;

$t_{i z i e}$ - time spent for a cow to leave the milking place on the rotary platform, s;

$k$ - milking time reserve coefficient, $k=0.5$ [1].

The time of the cycle of rotary equipment rotation can be calculated also according to its exploitation parameters 


$$
T_{c . k . e k s}=\frac{3600 \cdot n_{a p}}{W_{e k s}},
$$

where $n_{a p}-$ number of milking places or milking clusters, pcs;

$W_{e k s}$ - productivity of equipment, cows $\cdot \mathrm{h}^{-1}$.

Every rotary type milking equipment has also the pre-set time of the rotation cycle $T_{\text {c.iest }}$, which theoretically should be the same as the parameters calculated according to the formula (2). Otherwise during milking it is necessary to stop the rotary equipment very often in order to get longer time for the cows to be milked to get higher milk yield.

Based on the formula given in literature [1], it is possible to calculate also the theoretically possible productivity of the rotary equipment

$$
W_{\text {teor }}=\frac{3600 \cdot n_{a p} k_{e k s}}{T_{c}},
$$

where $k_{\text {eks }}$ - exploitation coefficient of equipment, $k=0.75$ [3].

Seven farms were selected for the research, where there is rotary type milking equipment used with different productivity of work, number of milking places (milking clusters), location of cows during milking and the number of milkers. The characterisation of the milk farms included in the research is summarised in Table 1.

Table 1

\begin{tabular}{|c|c|c|c|c|c|c|c|}
\hline \multirow[b]{2}{*}{ Indicator } & \multicolumn{7}{|c|}{ Name of the farm } \\
\hline & $\mathbf{A}$ & B & C & D & $\mathbf{E}$ & $\mathbf{F}$ & G \\
\hline $\begin{array}{l}\text { Number of } \\
\text { cows in herd }\end{array}$ & 300 & 600 & 430 & 430 & 570 & 2000 & 670 \\
\hline $\begin{array}{l}\text { Company } \\
\text { producing } \\
\text { milking } \\
\text { equipment }\end{array}$ & $\begin{array}{l}\text { GEA Farm } \\
\text { Tehnolo-gies }\end{array}$ & $\begin{array}{l}\text { GEA Farm } \\
\text { Tehnolo-gies }\end{array}$ & $\begin{array}{l}\text { GEA Farm } \\
\text { Tehnolo- } \\
\text { gies }\end{array}$ & De Laval & De Laval & $\begin{array}{c}\text { GEA Farm } \\
\text { Tehnolo- } \\
\text { gies }\end{array}$ & $\begin{array}{l}\text { GEA Farm } \\
\text { Tehnolo-gies }\end{array}$ \\
\hline $\begin{array}{l}\text { Milking } \\
\text { equip-ment }\end{array}$ & $\begin{array}{l}\text { Auto Rotor } \\
\text { Magnum } 40\end{array}$ & $\begin{array}{l}\text { Auto Rotor } \\
\text { Magnum } 40\end{array}$ & $\begin{array}{l}\text { Auto Rotor } \\
\text { Magnum } 40\end{array}$ & PR2100 & PR2100 & $\begin{array}{l}\text { Auto Rotor } \\
\text { Performer }\end{array}$ & $\begin{array}{l}\text { Auto Rotor } \\
\text { Magnum } 40\end{array}$ \\
\hline $\begin{array}{c}\text { Number of } \\
\text { milking } \\
\text { places }\end{array}$ & 20 & 50 & 36 & 34 & 50 & 80 & 32 \\
\hline $\begin{array}{c}\text { Number of } \\
\text { milkers }\end{array}$ & 2 & 2 & 2 & 2 & 3 & 4 & 2 \\
\hline $\begin{array}{c}\text { Cow } \\
\text { mechanical } \\
\text { driver }\end{array}$ & $\begin{array}{c}\text { Cow Mander } \\
015\end{array}$ & $\begin{array}{c}\text { Cow } \\
\text { Mander640 }\end{array}$ & $\begin{array}{c}\text { Cow } \\
\text { Mander600/ } \\
700\end{array}$ & $\begin{array}{c}\text { Cow } \\
\text { Moover OH }\end{array}$ & $\begin{array}{c}\text { HRS } \\
\text { Herdsmann }\end{array}$ & $\begin{array}{c}\text { Cow } \\
\text { Mander740 }\end{array}$ & $\begin{array}{c}\text { Cow Mander } \\
640\end{array}$ \\
\hline
\end{tabular}

Characterisation of the milk farms included in the research

During the research morning and evening milkings were timed. After that the corresponding operational parameters were calculated using the above given formulas.

\section{Results and discussion}

Having the information available in literature [1] it is possible to calculate according to the formula (1) that the length of the average milking cycle for milking one cow is $498 \mathrm{~s}$ or 8.3 minutes. The rotary type equipment exploitation indicators, obtained in the result of timekeeping, are summarised in Table 2.

The information obtained in theoretical calculations on the rotary equipment rotation cycle time is given in Figure 1. There are also the results of the research in its exploitation as well as the information on the programmed at farms rotary equipment rotation cycle time summarised (Figure 1). 
Rotary type milking equipment exploitation parameters

\begin{tabular}{|c|c|c|c|c|c|c|c|}
\hline \multirow{2}{*}{ Indicators } & \multicolumn{7}{|c|}{ Name of the farm } \\
\cline { 2 - 8 } & A & B & C & D & E & F & G \\
\hline $\begin{array}{c}\text { Number of } \\
\text { milking places }\end{array}$ & 20 & 50 & 36 & 34 & 50 & 80 & 32 \\
\hline $\begin{array}{c}\text { Pre-set (programmed) time of one } \\
\text { rotation, } T_{\text {apgr. }} \text { min. }\end{array}$ & 7.3 & 8.0 & 7.2 & 9.3 & 11.3 & 10.0 & 8.0 \\
\hline $\begin{array}{c}\text { Exploitation time of one rotation, } \\
T_{\text {eks. } \text { min. }}\end{array}$ & 12.6 & 15.0 & 14.9 & 14.8 & 14.3 & 15.0 & 14.8 \\
\hline $\begin{array}{c}\text { Productivity of work, } \mathrm{W}_{\text {eks. }} \\
\text { cow. } \mathrm{h}^{-1}\end{array}$ & 95 & 200 & 145 & 138 & 210 & 320 & 130 \\
\hline $\begin{array}{c}\text { Theoretical productivity of work, } \\
W_{\text {teor. } \text {. cow. }} \mathrm{h}^{-1}\end{array}$ & 108 & 271 & 195 & 184 & 271 & 434 & 173 \\
\hline
\end{tabular}

The figure shows that the pre-set rotary equipment rotation cycle time approximately corresponds to the calculated rotation cycle time $-8.3 \mathrm{~min}$. Exceptions are stated in two farms: $E$, where this time is $11.3 \mathrm{~min}$. or $36 \%$ longer, and in farms $F-10.0 \mathrm{~min}$. or $20 \%$ longer. Nevertheless, in most cases the rotary equipment rotation cycle in farms (during exploitation) is usually within the range from 12.6 to $15.0 \mathrm{~min}$., so this cycle time exceeds the theoretically calculated cycle time $1.5-1.8$ times. It shows that the time of one revolution of rotary equipment is considerably longer than the average milking time. There can be different reasons for that: rotary equipment idle time due to longer milking time of separate cows, technical failures as well as milkers' absence from work.

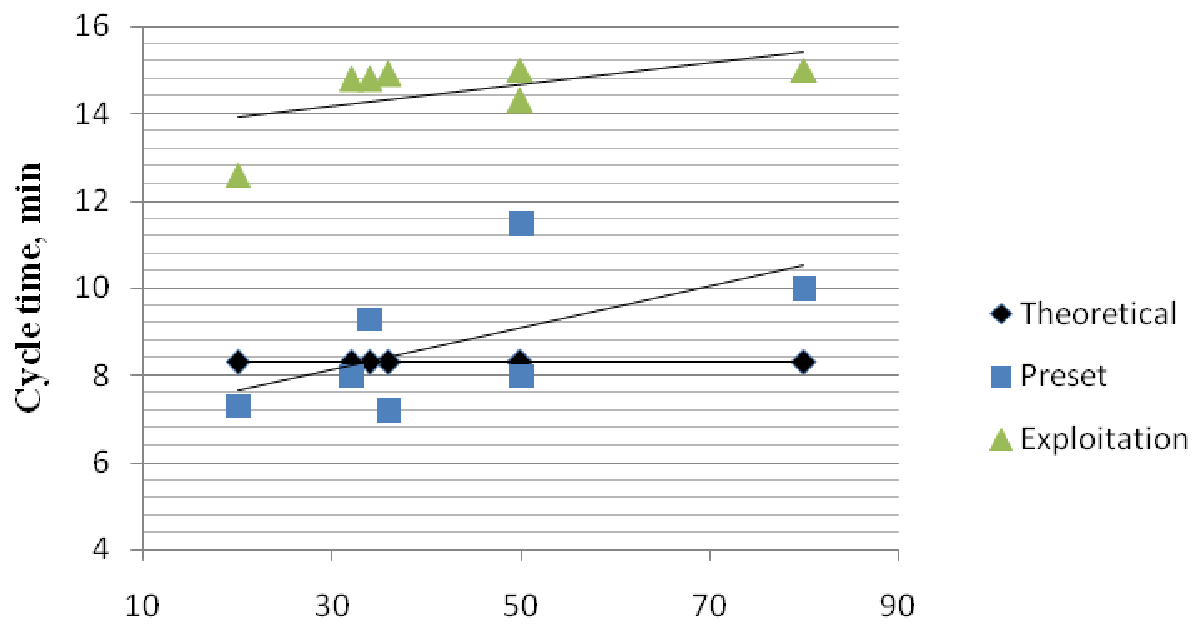

Number of milking place

Fig. 1. Rotary equipment rotation cycle time depending on number of cow milking sites

All these factors, of course, influence also the productivity of rotary equipment exploitation (Figure 2).

The figure shows that despite the comparatively different pre-set rotary equipment rotation cycle times the productivity of exploitation work is directly proportional to the number of milking places (regression coefficient $R^{2}=0.9937$ ) [10]. Also the theoretically calculated rotary equipment productivity of work varies proportionally to the number of milking sites. Nevertheless, it is by 25$35 \%$ higher than the exploitation productivity of work. It can be explained by the above mentioned delays of the rotary equipment rotation cycle times that is practically unavoidable during exploitation.

More detailed information on the influence of the pre-set rotary equipment rotation cycle time on the rotary equipment exploitation productivity of work can be seen in Figure 3. 


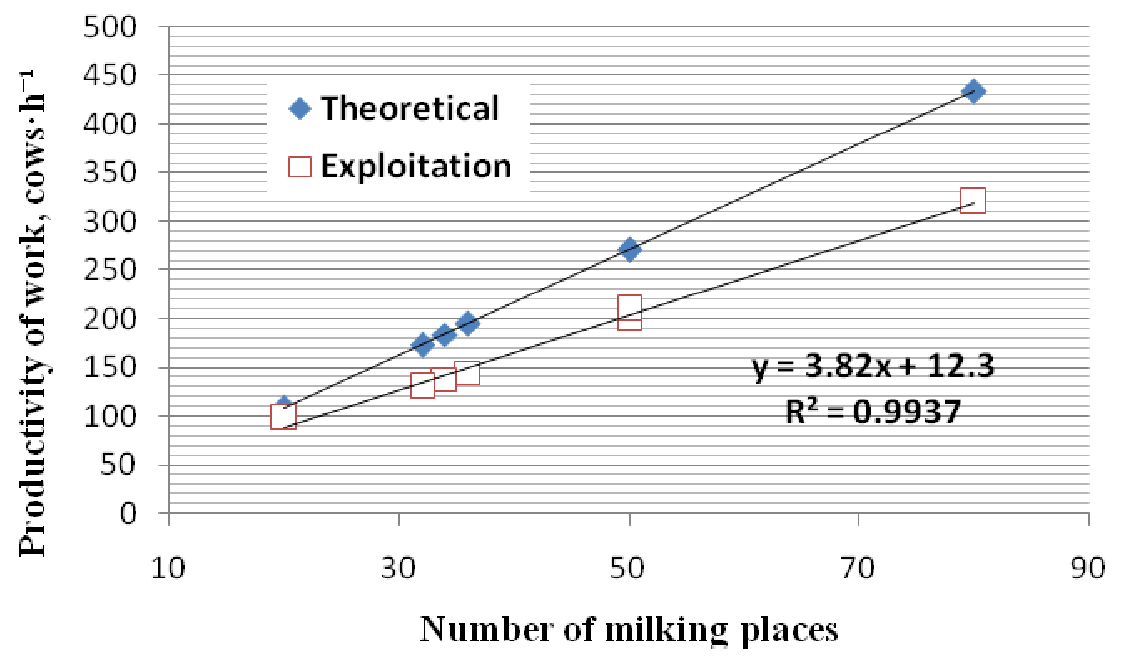

Fig. 2. Theoretical and actual rotary equipment productivity of work depending on number of milking sites

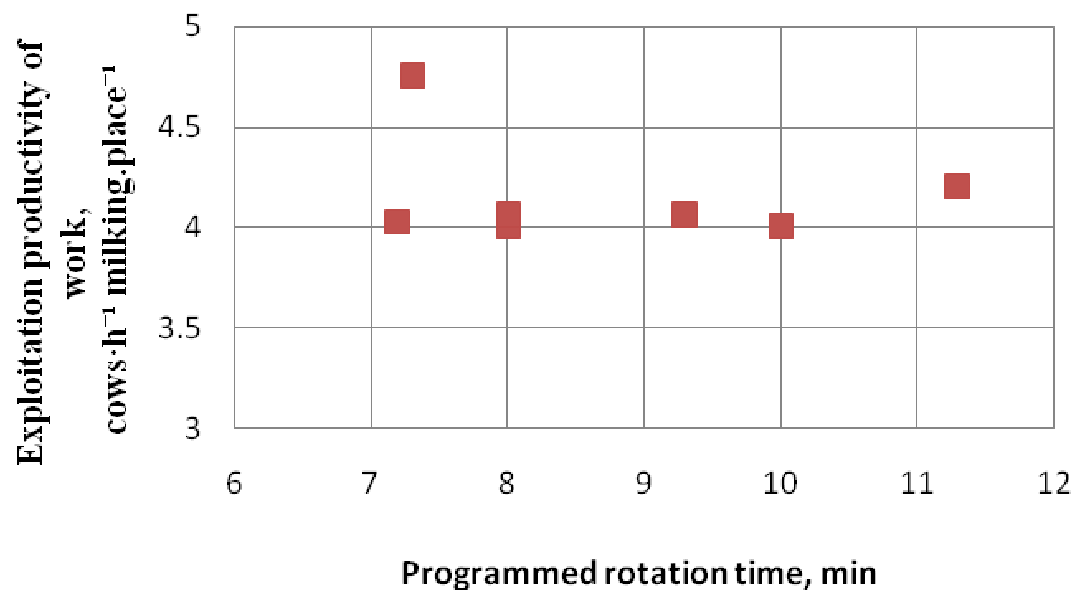

Fig. 3. Specific productivity of work of one rotary equipment milking place, $\operatorname{cows}^{\cdot} \cdot \mathbf{h}^{-1}$, depending on programmed rotation cycle time

As the figure shows, using any type of rotary equipment it is possible to milk about 4 cows per hour in one milking place. Besides, this indicator does not depend on the number of milking places in the rotary equipment as well as on the pre-set platform rotation or cycle time. An exception was stated only in one farm $-A$, where this indicator is 4.75 cows per hour. It can be explained by the wellconsidered organisation of work and selection of cows that need long milking, what reduces the necessity for forced stoppage of the rotary equipment and increases the exploitation work productivity.

\section{Conclusions}

1. For rotary type milking equipment the pre-set rotation cycle time is approximately equal to the theoretically calculated cycle time, and in most cases that is within the range from 7 to 10 minutes. In turn, the rotary equipment working cycle time, working in exploitation conditions, is 1.5-1.8 times longer than the theoretically calculated cycle time, and it is usually within the range from 12.6 to 15.0 minutes.

2. For the rotary type equipment included in the research, where there are not more than 80 milking saites, the exploitation productivity of work is directly proportional to the number of milking sites.

3. The specific exploitation productivity of work of the rotary equipment that is calculated per one milking site almost in all cases is approximately 4 cows per hour, besides, in the research its dependence on the pre-set rotation cycle time of the rotary equipment has not been found. 


\section{References}

[1] Modern milk production farm: technology, machinery, operation./ ed. J.Priekulis. Jelgava: LLU, 2013, 240 lpp. (In Latvian)

[2] Ozolins A., Priekulis J.,Laurs A. Research in rotary parlour operation. International conference "Engineering for Rural Development", May 24- 25, 2012, Jelgava, Latvia, pp. 43- 46.

[3] Edwards J. P., Lopez-Villalobos N., Jago J. G. Increasing platform speed and the percentage of cows completing a second rotation improves throughput in rotary dairies. Animal Production Science 52(10), 2012, pp. 969-973.

[4] Stal M., Pinzke S., Hansson GA., Kolstrup C. Highly repetitive work operations in a modern milking system. A case study of wrist positions and movements in a rotary system. Ann Agric Environ Med 2003, 10, pp. 67-72.

[5] Kic P. Criteria for optimization of milking parlour on dairy farm./14th International Scientific Conference "Engineering for Rural Development". Proceedings, Volume 13. Jelgava, Latvia, May 20-22, 2015, pp. 106-111.

[6] Gaworski M., Rocha A.G.F. Effect of management practices on time spent by cows. International conference "Engineering for Rural Development", Jelgava, Latvia, May 25-27, 2016, pp. 1300-1304.

[7] Nitzan R., Bruckental I., Bar Shira Z. Stochastic Models for simulating parallel, rotary and sideopening milking parlours. Journal of Dairy Science, vol. 89, No.11, 2006.

[8] Dijkstra C., Veermae I., Praks J., Poikalainen V., Arney D.R. Dairy Cow Behavior and

[9] Welfare Implications of Time Waiting Before Entry Into the Milking Parlor. Journal of Applied

[10] Animal Welfare Science 15:4, 2012, pp. 329-345.

[11] Ketelaar-deLauwere C.C., Devir S., Metz J.H.M. The influence of social hierarchy on the time budget of cows and their visits to an automatic milking system. Applied Animal Behaviour Science 49, 1996, pp. 199-211.

[12] Arhipova I., Bāliņa S. Statistics in Economics. R. DatorzinībuCentrs. 2003, 351 p. (In Latvian) 